\title{
In situ nutrient assays of periphyton growth in a lowland Costa Rican stream
}

\author{
Catherine M. Pringle*1, Pia Paaby-Hansen ${ }^{2}$, Peter D. Vaux ${ }^{2} \&$ Charles R. Goldman ${ }^{2}$ \\ ${ }^{1}$ School of Natural Resources, The University of Michigan, Ann Arbor, MI 48109, USA and ${ }^{2}$ Division \\ of Environmental Studies, The University of California, Davis, CA 95616, USA
}

Keywords: in situ bioassays, periphyton, tropical stream

\begin{abstract}
Nutrient limitation of primary production was experimentally assessed using an in situ bioassay technique in the Quebrada Salto, a third-order tropical stream draining the northern foothills of the Cordillera Central. in Costa Rica. Bioassays employed artificial substrata enriched with nutrients that slowly diffuse through an agar-sand matrix (Pringle \& Bowers, 1984). Multiple comparisons of regression coefficients, describing chlorophyll- $a$ accrual through time for different nutrient treatments, revealed positive micronutrient effect(s). Micronutrient treatment combinations ( $\mathrm{Fe}, \mathrm{B}, \mathrm{Mn}, \mathrm{Zn}, \mathrm{Co}, \mathrm{Mo}, \mathrm{EDTA}$ ), supplemented with and without nitrate and phosphate, exhibited significantly greater chlorophyll- $a$ accrual over all other treatments $(P<0.05)$, supporting over three times that of the control after 14-d of substratum colonization. Neither of the major nutrients ( $N$ or $P$ ) produced a significant stimulation, although the $\mathrm{N}$ treatment displayed $\simeq 50 \%$ more chlorophyll $-a$ than the control after 14-d. Similarly, Si, EDTA, and Si $+N+P$ treatments did not exhibit chlorophyll- $a$ response curves that were significantly different from the control. During the experiment, mean $\mathrm{NH}_{4}-\mathrm{N}$ and $\left(\mathrm{NO}_{2}+\mathrm{NO}_{3}\right)-\mathrm{N}$ concentrations in the Salto were $2.0 \mu \mathrm{M}\left(28.6 \mu \mathrm{g} \cdot 1^{-1}\right)$ and $7.2 \mu \mathrm{M}\left(100.2 \mu \mathrm{g} \cdot 1^{-1}\right)$, respectively. High concentrations of $\mathrm{PO}_{4}-\mathrm{P}\left(\overline{\mathrm{x}}=2.0 \mu \mathrm{M} ; 60.9 \mu \mathrm{g} \cdot 1^{-1}\right)$ and $\mathrm{TP}$ $\left(\overline{\mathrm{x}}=3.0 \mu \mathrm{M} ; 94.0 \mu \mathrm{g} \cdot \mathrm{1}^{-1}\right)$ were also found, and consequently low molar N:P ratios $(\overline{\mathrm{x}}=4.7)$. Despite the potential for $\mathrm{N}$ limitation in the system, both $\mathrm{N}$ and $\mathrm{P}$ appear to be at growth saturating levels. This may be due to micronutrient limitation and/or light limitation of periphyton growth in densely shaded upstream portions of the stream.
\end{abstract}

\section{Introduction}

Nutrient limiting factors have been studied in a variety of temperate and arctic streams and regional information has been compiled. Many streams in desert/semi-desert areas of the southwestern US (Cole \& Batchelder, 1969; Sommerfeld et al., 1974; Grimm et al., 1981) and the Pacific Northwest (Gregory, 1980) are suspected or have been found to be nitrogen limited, exhibiting low $\mathrm{N}: \mathrm{P}$ ratios. In

\footnotetext{
* Address to which correspondence should be sent: Catherine M. Pringle, Department of Botany, The University of California, Berkeley, CA 94720, USA
}

contrast, streams of the eastern US, draining predominantly forested watersheds, have been found to exhibit relatively high molar N:P ratios of 68:1, suggesting phosphorus limitation (Omernik, 1977). Likewise, periphyton populations in pristine streams in the midwestern US (Pringle \& Bowers, 1984), the southern US (Elwood et al., 1981), northern Canada (Stockner \& Shortreed, 1978) and arctic Alaska (Peterson et al., 1983), have been stimulated by in situ additions of phosphorus, exhibiting little or no response to nitrogen additions (also indicating phosphorus limitation).

Nutrient limitation of periphyton abundance is poorly understood in tropical lotic systems relative 
to the amount of information that exists for temperate streams. This is unfortunate given the rapid degradation of tropical watersheds and the abundant evidence that deforestation can severely alter nutrient input from the watershed (e.g. Bormann \& Likens, 1979). An increasing amount of work has been done in the Amazon (Sioli, 1975; Tundisi \& Curi, 1984; Setaro \& Melack, 1984), however, other areas have remained unexplored. Specifically, the nutrient chemistry of Costa Rica's Atlantic and Pacific slope streams is little known and, to our knowledge, no in situ manipulations have been attempted. Many of these watersheds are underlain by volcanic basalt and are generally characterized by young soils that contain more phosphorus relative to older soils of the Amazon (Vitousek, 1984). Virtually nothing is known regarding how this geochemistry is reflected by stream nutrient chemistry and primary production.

In this study we report preliminary analyses of nutrient chemistry for a stream in Costa Rica which flows through a remnant of primary rainforest. Using an in situ substratum enrichment technique (Pringle \& Bowers, 1984), we evaluated nutrient limitation of periphyton growth.

\section{Description of study site}

The study site was located in the lower watershed of the Quebrada Salto, a river that drains the Atlantic slope foothills of Costa Rica's Cordillera Central, dropping from $300 \mathrm{~m}$ to $\approx 36 \mathrm{~m}$ above sea level where it empties into the Rio Puerto Viejo. The lower watershed of the Salto is located in the La Selva Biological Reserve $\left(10^{\circ} 26^{\prime} \mathrm{N}, 84^{\circ} 00^{\prime} \mathrm{W}\right)$, owned and operated by the Organization for Tropical Studies. The upper two thirds of the river is contained within 'Zona Protectora La Selva', a corridor of land that comprises part of the last altitudinal transect of tropical rainforest remaining in Central America. According to topographic and land-use maps (Pringle et al., 1984), less than 5\% of the Salto's watershed is estimated to be in pasture and secondary forest. In general, the Salto is heavily shaded by many overhanging trees. At the study site, where La Selva's Central Trail crosses the river via a bridge, the canopy is relatively open allowing direct sunlight penetration for $\simeq 3-4 \mathrm{~h} \cdot \mathrm{d}^{-1}$. The Salto is a third-order stream at this point and river bed sediments range from fine gravel to large boulders.

The Salto watershed lies in an area of basaltic bedrock overlain by residual volcanic soils derived from this parent material (Bourgeois et al., 1972). Though soils are highly weathered, they are classified as inceptisols and entisols, which are more fertile relative to older soils characteristic of many tropical areas.

\section{Materials and methods}

In constructing nutrient-diffusing substrata, quartz sand (medium particle size) was washed and autoclaved to kill attached microorganisms, then consolidated into plastic disposable petri dishes (5.2 cm diameter; $1.2 \mathrm{~cm}$ deep) with $2.0 \%$ agar solutions enriched with various nutrients according to the method of Pringle \& Bowers (1984). Each bioassay plate consisted of $10 \mathrm{ml}$ of agar and $\approx 40 \mathrm{~g}$ of sand. Treatments included the following: (a) control (unenriched agar), (2) nitrate $(0.50 \mathrm{M}$ $\mathrm{NaNO}_{3}$ ), (3) phospate (0.50 $\left.\mathrm{M} \mathrm{KH}_{2} \mathrm{PO}_{4}\right)$, (4) micronutrient combination $\left(0.03 \mathrm{M} \mathrm{FeC} \mathrm{F}_{5} \mathrm{O}_{7}\right.$, $0.01 \mathrm{M} \quad \mathrm{H}_{3} \mathrm{BO}_{3}, \quad 0.02 \mathrm{M} \quad \mathrm{MnCl}_{2} \cdot 4 \mathrm{H}_{2} \mathrm{O}$, $3.01 \times 10^{-4} \mathrm{M} \quad \mathrm{ZnCl}_{2}, \quad 3.79 \times 10^{-5} \mathrm{M}$ $\mathrm{CoCl}_{2} \cdot 6 \mathrm{H}_{2} \mathrm{O}, 3.06 \times 10^{-4} \mathrm{M} \quad \mathrm{Na}_{2} \mathrm{MoO}_{4} \cdot 2 \mathrm{H}_{2} \mathrm{O}$, and $4.46 \times 10^{-3} \mathrm{M}$ EDTA), (5) micronutrient combination (see \#4), nitrate and phosphate $\left(1.50 \mathrm{M} \quad \mathrm{NaNO}_{3}\right.$, and $0.09 \mathrm{M} \quad \mathrm{KH}_{2} \mathrm{PO}_{4}$; $\mathrm{N}: \mathrm{P}=16: 1)$, (6) silicate $\left(0.10 \mathrm{M} \mathrm{Na}_{2} \mathrm{SiO}_{3} \cdot 5 \mathrm{H}_{2} \mathrm{O}\right)$, (7) silicate, nitrate and phosphate $(0.10 \mathrm{M}$ $\mathrm{Na}_{2} \mathrm{SiO}_{3} \cdot 5 \mathrm{H}_{2} \mathrm{O}, 1.50 \mathrm{M} \mathrm{NaNO}_{3}$, and $0.09 \mathrm{M}$ $\left.\mathrm{KH}_{2} \mathrm{PO}_{4} ; \mathrm{N}: \mathrm{P}=16: 1\right)$, (8) EDTA $\left(4.46 \times 10^{-3} \mathrm{M}\right.$ EDTA). The EDTA treatment assessed bioavailability of metals in the water (Goldman \& Horne, 1983). Micronutrient ratios followed those used by Moss (1972) for lentic systems and were scaled to one tenth of the $\mathrm{KH}_{2} \mathrm{PO}_{4}$ concentration used in treatment 5 . Treatment combinations were chosen to help identify potential limiting factors that might not be apparent if only single nutrient spikes were used (Schelske, 1984).

Nutrient enriched substrata were glued onto wooden boards in a non-random design which clumped replicates within treatments to minimize lateral and downstream nutrient effects between treatments. Boards were subsequently installed within the Quebrada Salto during the rainy season 
in September, 1984. Care was taken to insure that differences between substratum treatments resulting from location effects were minimal by locating substrata in a narrow range of current velocities and uniform light. Boards were placed $\simeq 10 \mathrm{~cm}$ below the water surface, $\approx 60 \mathrm{~cm}$ above the stream bottom, and were oriented so that substratum surfaces were parallel to the current flow. Boards were secured in this position by tying them securely to wooden projections that extended outward from a wooden bridge that spans the stream at the study site. Artificial substrata were checked 1-2 times daily throughout the experiment and cleared of any accumulated debris. Three replicate substrata per treatment were retrieved at 5,10 , and $14 \mathrm{~d}$ intervals for analysis of chlorophyll- $a$ accumulation. Previous studies in the Quebrada Salto (Paaby \& Phillips, unpubl. data), indicated that substantial periphyton populations developed on glass slides after a $14 \mathrm{~d}$ period.

Upon retrieval, the upper $3 \mathrm{~mm}$ of agar and sand were carefully removed with a razor blade. The layer was placed in a $200 \mathrm{ml}$ beaker, diluted with $100 \mathrm{ml}$ of distilled water and then mixed for $10 \mathrm{~min}$ with a magnetic stirrer. This procedure (Pringle \& Bowers, 1984) resulted in almost complete periphyton separation from sand grains, as evidenced by microscopic scanning of residual grains. Samples $(2.0 \mathrm{ml})$ taken from the suspended homogenate were filtered $(0.45 \mu \mathrm{m}$ Millipore filters) and then placed in $5 \mathrm{ml}$ of buffered, $90 \%$ acetone and stored frozen in dark bottles for 2 wks until analyzed. The fluorescence of extracted chlorophyll- $a$ was subsequently determined on a Turner III fluorometer according to standard methods (APHA, 1980). Values were corrected for phaeophytin and expressed in $\mathrm{mg}$ chlorophyll- $a \cdot \mathrm{m}^{-2}$ substratum surface. Multiple comparisons of regression coefficients, describing chlorophyll- $a$ accrual through time for different treatments, were made via a simultaneous test procedure (Sokal \& Rohlf, 1981).

Ambient water chemistry was monitored throughout the duration of the experiment every 1-2 d (and twice a day for a period of $4 \mathrm{~d}$ ). Two replicate water samples were collected on each sampling date and filtered through pre-rinsed, Whatman (GFC) glass-fiber filters; two replicate unfiltered samples were also collected. Water samples were stored frozen in polyethylene bottles and shipped frozen back to the University of Califor- nia, Davis, for chemical analyses. Soluble reactive phosphorus $\left(\mathrm{PO}_{4}-\mathrm{P}\right)$ and total phosphorus (TP) were measured with the molybdenum blue technique (preceded by acid hydrolysis in the case of TP analyses; APHA, 1980). Filtered samples were analyzed for $\left(\mathrm{NO}_{2}+\mathrm{NO}_{3}\right)-\mathrm{N}$ using the hydrazine reduction method (Kamphake et al., 1967). Ammonia, iron and silica analyses were carried out on unfiltered samples using the indophenol method (Solorzano, 1969), the ferrozine technique (Stookey, 1970), and the molybdosilicate complex method (APHA, 1980), respectively. Cations (Zn, $\mathrm{Ca}, \mathrm{Mg}, \mathrm{Na}, \mathrm{K}$ ) were measured with atomic absorption spectrometry. Temperature and oxygen were monitored daily using a combined oxygentemperature meter (YSI model). Alkalinity was determined potentiometrically and $\mathrm{pH}$ was measured with an Orion probe. Suspended solids concentrations were determined by filtering known quantities of water through pre-weighed Whatman (GFC) glass-fiber filters, drying at $103^{\circ} \mathrm{C}$ and reweighing. Water level fluctuations were recorded daily and current velocities of waters flowing over artifical substrata were measured at the beginning of the experiment by timing the distance traveled by a small plastic float (Hynes, 1970).

\section{Results}

Analysis of substratum plates after $14 \mathrm{~d}$ indicated that chlorophyll- $a$ accumulations on the micronutrient treatment $\left(26.7 \pm 2.8 \mathrm{mg} \cdot \mathrm{m}^{-2}\right)$ and the micronutrient $+\mathrm{N}+\mathrm{P}$ treatment $\left(30.7 \pm 1.8 \mathrm{mg} \cdot \mathrm{m}^{-2}\right)$ were over three times those of control substrata $\left(8.6 \pm 0.5 \mathrm{mg} \cdot \mathrm{m}^{-2}\right)$. Chlorophyll- $a$ levels, $\simeq 50 \%$ greater than those of the control, were displayed by the $\mathrm{N}$ treatment $\left(13.1 \pm 1.1 \mathrm{mg} \cdot \mathrm{m}^{-2}\right)$ and the $\mathrm{Si}+\mathrm{N}+\mathrm{P}$ treatment $\left(13.7 \pm 1.1 \mathrm{mg} \cdot \mathrm{m}^{-2}\right.$; Fig. 1 , Table 1$)$.

A one-way ANOVA indicated that some treatment effects were highly significant $(\mathrm{P}<0.01)$. A simultaneous test procedure showed that the micronutrient and the micronutrient $+\mathrm{N}+\mathrm{P}$ treatments were significantly higher than the control and all other treatments, though not significantly different from each other $(P<0.05)$. No significant differences $(P<0.05)$ were found between regression coefficients describing chlorophyll- $a$ accrual through time for control, 


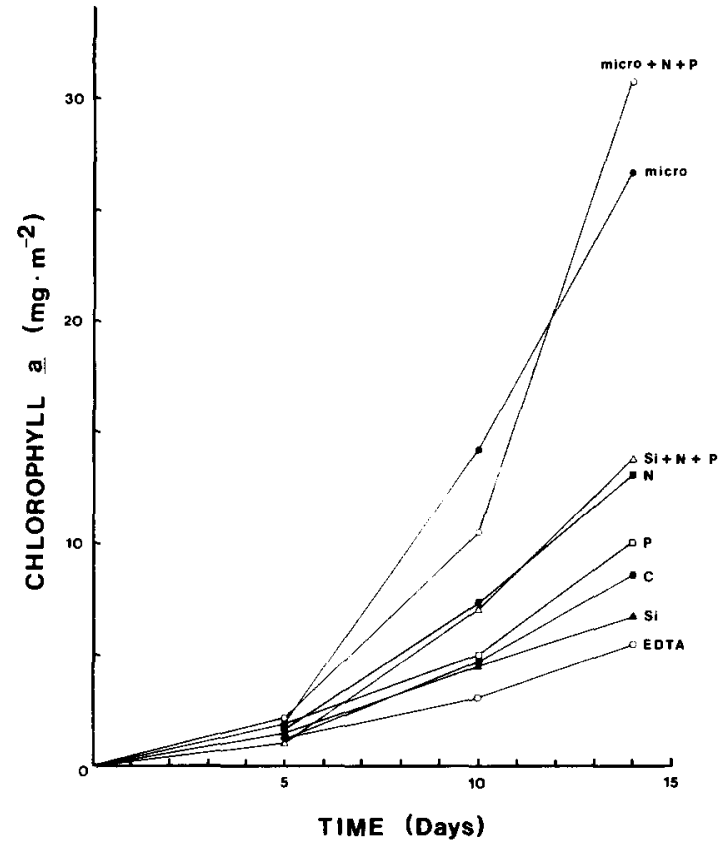

Fig. 1. Mean chlorophyll- $a$ accrual on bioassay substrata after 5, 10 and $14 \mathrm{~d}$ of in situ exposure in the Quebrada Salto; Where: micro $=$ micronutrient $\quad$ combination; $\quad N=$ nitrate; $P=$ phosphate; $S i=$ silicate; and $C=$ control (see Table 1 for standard error associated with plotted means).
Table 1. Mean chlorophyll- $a$ accrual \pm standard error upon bioassay substrata during the experiment. Substratum retrieval dates were September 15, 20, and 24, 1984. (See Fig. 1 for treatment explanation code.)

\begin{tabular}{llrr}
\hline \multirow{2}{*}{ Treatment } & \multicolumn{3}{l}{ Substratum exposure period } \\
\cline { 2 - 4 } & \multicolumn{1}{l}{$5-\mathrm{d}$} & \multicolumn{1}{l}{$10-\mathrm{d}$} & \multicolumn{1}{c}{$14-\mathrm{d}$} \\
\hline $\mathrm{C}$ & $1.3 \pm 0.1$ & $4.8 \pm 0.5$ & $8.6 \pm 0.5$ \\
$\mathrm{~N}$ & $1.7 \pm 0.3$ & $7.4 \pm 0.7$ & $13.1 \pm 1.1$ \\
$\mathrm{P}$ & $1.9 \pm 0.3$ & $5.0 \pm 0.9$ & $10.1 \pm 0.4$ \\
Micro & $1.8 \pm 0.2$ & $14.2 \pm 1.5$ & $26.7 \pm 2.8$ \\
Micro $+\mathrm{N}+\mathrm{P}$ & $2.2 \pm 0.3$ & $10.5 \pm 2.4$ & $30.7 \pm 1.8$ \\
Si & $1.5 \pm 0.2$ & $4.5 \pm 0.3$ & $6.7 \pm 1.0$ \\
Si $+\mathrm{N}+\mathrm{P}$ & $1.0 \pm 0.4$ & $7.0 \pm 0.5$ & $13.7 \pm 1.1$ \\
EDTA & $1.2 \pm 0.1$ & $3.1 \pm 0.2$ & $5.5 \pm 1.1$ \\
\hline
\end{tabular}

EDTA, Si, P, N, and $\mathrm{Si}+\mathrm{N}+\mathrm{P}$ treatments.

Chemical and physical conditions of the Quebrada Salto are summarized in Table 2. Rates of water flow over artificial substratum plates ranged from $32.0-40.0 \mathrm{~cm} \cdot \mathrm{s}^{-1}$ and water levels were usually within $3 \mathrm{~cm}$ of the mean gauge reading (total range $=19 \mathrm{~cm}$ ). Macroinvertebrate grazer populations were very low at the study site and virtually no grazers colonized artificial substrata.

Table 2. Ranges, means and standard deviations for measurements of physical and chemical variables in the Quebrada Salto during the bioassay experiment.

\begin{tabular}{|c|c|c|c|c|c|c|}
\hline Variable & Unit & $\begin{array}{l}\text { No. of } \\
\text { observations }\end{array}$ & Min. & Max. & Mean & $\begin{array}{l}\text { Standard } \\
\text { deviation }\end{array}$ \\
\hline $\mathrm{SRP}\left(\mathrm{PO}_{4}-\mathrm{P}\right)$ & $\mu \mathrm{M}$ & 24 & 1.2 & 2.4 & 2.0 & 0.3 \\
\hline Total $\mathbf{P}$ & $\mu \mathrm{M}$ & 24 & 2.5 & 3.6 & 3.0 & 0.3 \\
\hline$\left(\mathrm{NO}_{2}+\mathrm{NO}_{3}\right)-\mathrm{N}$ & $\mu \mathrm{M}$ & 24 & 1.4 & 11.4 & 7.2 & 3.2 \\
\hline $\mathrm{NH}_{4}-\mathrm{N}$ & $\mu \mathrm{M}$ & 21 & 1.4 & 2.7 & 2.0 & 0.3 \\
\hline$N: P^{i}$ & $\mu \mathrm{M}$ & 20 & 2.1 & 6.1 & 4.7 & - \\
\hline Total Fe & $\mu \mathrm{M}$ & 23 & 5.7 & 24.6 & 9.3 & 4.7 \\
\hline $\mathrm{Si}$ & $\mu \mathrm{M}$ & 26 & 391.5 & 569.4 & 495.4 & 14.3 \\
\hline $\mathrm{Zn}$ & - & 4 & \multicolumn{3}{|c|}{ below detection } & - \\
\hline $\mathrm{Ca}$ & $\mu \mathrm{M}$ & 4 & 49.6 & 155.8 & 122.2 & 47.4 \\
\hline $\mathrm{Mg}$ & $\mu \mathrm{M}$ & 4 & 62.9 & 266.3 & 209.9 & 98.8 \\
\hline $\mathrm{Na}$ & $\mu \mathrm{M}$ & 4 & 95.3 & 364.7 & 276.8 & 122.7 \\
\hline K & $\mu \mathrm{M}$ & 4 & 34.8 & 98.5 & 76.3 & 28.3 \\
\hline Temperature & ${ }^{\circ} \mathrm{C}$ & 12 & 23.4 & 24.9 & 23.9 & 0.4 \\
\hline Oxygen & $\mathrm{mg} \cdot 1$ & 12 & 7.2 & 8.3 & 7.6 & 0.3 \\
\hline Total alkalinity & $\mathrm{mg} \mathrm{CaCO}{ }^{3} \cdot 1^{-1}$ & 12 & 27.3 & 52.5 & 42.8 & 7.4 \\
\hline $\mathrm{pH}$ & - & 12 & 6.4 & 6.9 & 6.7 & 0.2 \\
\hline Suspended solids & $\mathrm{mg} \cdot \mathrm{l}^{-1}$ & 15 & 3.3 & 7.9 & 6.8 & 4.3 \\
\hline
\end{tabular}

1 Where $\mathrm{N}: \mathrm{P}=\left(\mathrm{NO}_{2}+\mathrm{NO}_{3}\right)-\mathrm{N}+\mathrm{NH}_{4}-\mathrm{N}: \mathrm{PO}_{4}-\mathrm{P}$. 


\section{Discussion}

Bioassay results reflect high ambient $N$ and $P$ levels, indicating that periphyton standing crop was not primarily limited by either of these macronutrients. Despite the potential for $\mathrm{N}$ limitation in the system [given high $\mathrm{PO}_{4}-\mathrm{P}$ and $\mathrm{TP}$ concentrations, with consequently low $\mathrm{N}: \mathrm{P}$ ratios $(\dot{\overline{\mathrm{x}}}=4.7)$, relative to Redfield's ratio of 16:1 (Redfield et al., 1963)], ambient $N$ and $P$ levels both appear to be at growth saturating conditions. The lack of periphyton response to $P$, coupled with high ambient $P$ levels $\left(\overline{\mathrm{x}}=2.0 \mu \mathrm{M} \mathrm{PO}_{4}-\mathrm{P}\right)$ is in accordance with studies of Elwood et al. (1981) which reveal that periphyton capacity for $\mathbf{P}$ uptake in a temperate stream was saturated at $2.0 \mu \mathrm{M} \mathrm{PO}_{4}-\mathrm{P}$.

Several other investigations have observed a lack of periphyton response to both $\mathrm{N}$ and $\mathrm{P}$ in lotic systems (Patrick, 1966; Kilkus et al., 1975; Moore, 1977). The streams studied, however, were disturbed nutrient-rich systems draining agricultural watersheds. The study of Wuhrmann \& Eichenberger (1975) is very similar to ours. They added $N$ and $\mathbf{P}$ to pristine ground water and detected no stimulation of periphyton growth, whereas trace metal mixtures and dilute sewage did elicit a response. In this latter study it is possible that initially high $\mathrm{N}$ and $\mathrm{P}$ levels in the ground water had not yet been depressed through metabolic uptake by photosynthetic organisms; water diverted through unshaded stream channels for a significant distance might have become P limited (Peterson et al., 1983). In a similar fashion, light limitation of periphyton populations in densely shaded upstream portions of our study stream may partially explain high ambient $\mathbf{N}$ and $\mathbf{P}$ concentrations. Thus, though micronutrient(s) appear to limit periphyton abundance at our study site and at the site of Wuhrmann \& Eichenberger (1975), the possibility that other factors (e.g. light) may be primarily limiting in other parts of the stream should not be overlooked.

The highly significant periphyton response to micronutrient treatments indicates the desirability of distinguishing among individual micronutrient effects within the combination employed in our preliminary experiment. Although several studies have assessed effects of individual and/or combined trace metal additions upon phytoplankton populations in lakes (e.g. Goldman, 1964; Henry \&
Tundisi, 1982), comparatively few have dealt with periphyton response in lotic systems (Patrick et al., 1969; Wuhrmann \& Eichenberger, 1975). Interpretation of results of such studies is often confounded by difficulties in measuring the biological availability of trace metals with conventional analytical methods (Schelske, 1984).

Possibly one or more trace metals are in short supply within the Salto watershed because of geological and/or biological phenomena. For instance, Goldman (1966) has shown that some ions (e.g. molybdate) are strongly absorbed to hydrated oxides of iron and manganese, which effectively remove them from aquatic environments that favor formation of these colloids. The Salto watershed provides such an environment. When basalt weathers, minerals are eventually converted to clay, aluminum and iron oxides (note high Fe levels in Table 2), with bases released into solution (Greenland, 1981).

Major questions arising from our study that we are currently pursuing include: (1) Which micronutrients limit periphyton growth, (2) Why are $\mathrm{PO}_{4}-\mathrm{P}$ and TP levels so high in the Salto relative to many undisturbed systems in temperate areas, and (3) What effects do such high levels have on nutrient cycling processes? Data for other rivers that also flow through primary forest within different watersheds on the La Selva Reserve, indicate similarly high $P$ levels in both rainy and/or dry seasons (Luvall \& Jordan, 1984; Glover \& Balthelt, unpubl. data; Pringle et al., unpubl. data). Factors governing bulk nutrient concentrations in freshwater systems include soil chemistry and exchange capacity, anthropogenic inputs into the watershed, precipitation and vegetation cover. Since terrestrial systems at La Selva are characterized by tropical andisols, which have a high phosphorus binding capacity (Parfitt, 1980), we speculate that high $\mathrm{PO}_{4}-\mathrm{P}$ and TP concentrations in the Salto arise from soil input and desorption processes. During our study, suspended sediment loads in the Salto were visibly high during periods of rainfall. The presence of high concentrations of iron, which is not soluble in oxic conditions, also indicates significant sediment inputs. Furthermore, the presence of ferric hydroxides implies removal of soluble phosphorus present in the system via adsorption (Nürnberg, 1984). This is reflected by high TP levels in unfiltered samples. Grobbelaar (1983) also 
reports high amounts of $\mathrm{P}$ absorbed onto suspended sediments in Amazon rivers, suggesting that adsorbed nutrients could substantially drain tropical ecosystems of phosphorus through sedimentation and/or discharge processes.

In conclusion, three lines of evidence indicate that periphyton growth was not primarily limited by either $\mathrm{N}$ or $\mathrm{P}$ at our study site during the experiment: (1) relatively high ambient $N$ and $P$ concentrations, (2) lack of periphyton response to in situ $\mathrm{N}$ and $\mathrm{P}$ additions, and (3) significant periphyton response to addition of micronutrients. As cited above, other studies have also recorded unusually high ambient $P$ levels in La Selva streams. Our study, combined with those observations, indicates that nutrient regulation of periphyton growth and nutrient cycling processes in lowland Costa $\mathrm{Ri}$ can streams warrant further investigation.

\section{Acknowledgements}

We gratefully acknowledge the support of the Organization for Tropical Studies who funded this project through an award from the Jessie Smith Noyes Foundation. We thank F. Hooper, P. and S. Kilham, D. White, J. Bowers, J. Stout, J. Reuter and V. Resh for their helpful comments on the manuscript. Special thanks are also extended to Mauri Janik who generously assisted with chemical analyses.

\section{References}

American Public Health Association, 1980. Standard methods for examination of water and wastewater, 14th Edn., APHA, $1193 \mathrm{pp}$.

Bormann, F. H. \& G. E. Likens, 1979. Catastrophic disturbance and the steady state in northern hardwood forests. Am. Sci. 67: $660-669$.

Bourgeois, W. W., D. W. Cole, H. Reikerk \& S. P. Gessel, 1972. Geology and soils of comparative ecosystem study areas, Costa Rica. Contrib. 11, Inst. For. Prod., Univ. Wash., 112 pp.

Cole, G. A. \& G. L. Batchelder, 1969. Dynamics of an Arizona travertine-forming stream. J. Ariz. Acad. Sci. 5: 271-283.

Elwood, J. W., J. D. Newbold, A. F. Trimble \& R. W. Stark, 1981. The limiting role of phosphorus in a woodland stream ecosystem: Effects of $P$ enrichment on leaf decomposition and primary producers. Ecology 62: 146-158.

Goldman, C. R., 1964. Primary productivity and micronutrient limiting factors in some North American and New Zealand lakes. Verh. int. Ver. Limnol. 15: $365-374$.
Goldman, C. R., 1966. Molybdenum as an essential micronutrient and useful watermass marker in Castle Lake, California. Proc. IBP Symp. Amst.: 229-238.

Goldman, C. R. \& A. J. Horne, 1983. Limnology. McGraw-Hill Book Co., N.Y., 464 pp.

Greenland, D. J., 1981. Soil management and soil degradation. J. Soil. Sci. 32: 301-312.

Gregory, S. V., 1980. Effects of light, nutrients and grazing on periphyton communities in streams. Ph.D. Thesis, Oregon St. Univ., Corvallis, OR, $150 \mathrm{pp}$.

Grimm, N. R., S. G. Fisher \& W. L. Minckley, 1981. Nitrogen and phosphorus dynamics in hot desert streams of southwestern USA. Hydrobiologia 83: 303-312.

Grobbelaar, J. U., 1983. Availability to algae of N and P adsorbed on suspended solids in turbid waters of the Amazonian River. Arch. Hydrobiol. 96: 302-316.

Henry, R. \& J. G. Tundisi, 1982. Evidence of limitation by molybdenum and nitrogen on the growth of the phytoplankton community of the Lobo Reservoir (São Paulo, Brazil). Revue Hydrobiol. trop. 15: 201-208.

Hynes, H. B. N., 1970. Ecology of running waters. University of Toronto Press, Toronto, $555 \mathrm{pp}$.

Kamphake, L. J., S. A. Hannah \& J. M. Cohen, 1967. Automated analysis for nitrate by hydrazine reduction. Wat. Res. 1: 205-216.

Kilkus, S. P., J. D. Laperriere \& R. W. Bachman, 1975. Nutrients and algae in some central Iowa streams. J. Wat. Pollut. Cont. Fed. 47: 1870-1879.

Luvall, J. \& C. Jordan, 1984. Chemical analyses of two watershed streams at La Selva Reserve, Costa Rica: Special Report on Watershed Feasibility Study. Orgn. trop. Stud., Univ. N. Carolina, Durham, NC, 34 pp.

Moore, J. W., 1977. Some factors affecting algal densities in a eutrophic farmland stream, Oecologia 29: 257-267.

Moss, B., 1972. The influence of environmental factors on the distribution of freshwater algae: An experimental study, 1. The influence of calcium concentration. J. Ecol. 60: 917-932.

Nürnberg, G., 1984. Iron and hydrogen sulfide interference in the analysis of soluble reactive $\mathbf{P}$ in anoxic waters. Wat. Res. 18: $327-369$.

Omernik, J. M., 1977. Nonpoint source-stream nutrient level relationships: a nationwide survey. EPA-600/3-77-105, Ecol. Res. Ser., USEPA, Washington, D.C.

Parfitt, R. L., 1980. Chemical properties of variable charge soils. In B. K. G. Theng (ed.), Soils with variable charge. NZ Soc. Soil Sci., Lower Hutt, NZ: 167-194.

Patrick, R., 1966. The effect of varying amounts and ratios of nitrogen and phosphorus on algal blooms. Proc. indian. Waste Conf. 21: 41-51.

Patrick, R., B. Crum \& J. Coles, 1969. Temperature and manganese as determining factors in the presence of diatom or bluegreen algal floras in streams. J. Phil. Nat. Acad. Sci. 64: $472-478$.

Peterson, B. J., J. E. Hobbie, T. L. Corliss \& D. Kriet, 1983. A continuous flow periphyton bioassay; Tests of nutrient limitation in a tundra stream. Limnol. Oceanogr. 28: 582-595.

Pringle, C. M. \& J. A. Bowers, 1984. An in situ substratum fertilization technique: Diatom colonization on nutrient enriched sand substrata. Can. J. Fish. aquat. Sci. 41: 1247-1251. 
Pringle, C. M., I. Chacón, M. H. Grayum, H. W. Greene, G. S. Hartshorn, G. E. Schatz, F. G. Stiles, C. Gomez \& M. Rodriguez, 1984. Natural history observations of the La Selva Protection Zone, Costa Rica. Brenesia 22: 189-206.

Redfield, A. C., B. H. Ketchum \& F. A. Richards, 1963. The influence of organisms on the composition of sea-water. In M. N. Hill (ed.), The Composition of Sea Water: Comparative and Descriptive Oceanography. Interscience, N.Y.: $26-77$.

Schelske, C. L., 1984. In situ and natural phytoplankton assemblage bioassays. In L. E. Schubert (ed.), Algae as Ecological Indicators. Academic Press, Inc., Lond.: 15-47.

Setaro, F. V. \& J. M. Melack, 1984. Responses of phytoplankton to experimental nutrient enrichment in an Amazon floodplain lake. Limnol. Oceanogr. 29: 972-984.

Sioli, H., 1975. Amazon tributaries and drainage basins. In A. D. Hasler (ed.), Coupling of Land Water Systems. Springer-Verlag, NY: 199-214.

Sokal, R. R. \& F. J. Rohlf, 1981. Biometry, (2nd Edn.), W. H. Freeman \& Co., San Francisco, 776 pp.
Solorzano, L., 1969. Determination of ammonia in natural waters by the phenol-hypochlorite method. Limnol. Oceanogr. 14: 799-801.

Sommerfeld, M. R., R. D. Olsen \& T. D. Love, 1974. Some chemical observations on the upper Salt River and its tributaries. J. Ariz. Acad. Sci. 9: 78-81.

Stockner, J. G. \& K. R. Shortreed, 1978. Enhancement of autotrophic production by nutrient addition in a coastal rainforest stream on Vancouver Island. J. Fish Res. Bd Can. 35: 28-34.

Stookey, L. L., 1970. Ferrozine, a new spectrophotometric reagent for iron. Analyt. Chem. 42: 779-781.

Tundisi, R. H. \& R. R. Curi, 1984. Effects of phosphorus and nitrogen enrichment on the phytoplankton in a tropical reservoir (Lobo Reservoir, Brazil). Hydrobiologia 118: 177-185.

Vitousek, P. M., 1984. Litterfall, nutrient cycling and nutrient limitation in tropical forests. Ecology 65: 285-298.

Wuhrmann, K. \& E. Eichenberger, 1975. Experiments on the effects of inorganic enrichment of rivers on periphyton primary production. Verh. int. Ver. Limnol. 19: 2028-2031. 